Kinestetik : Jurnal Ilmiah Pendidikan Jasmani 5 (4) (2021)

Kinestetik : Jurnal Ilmiah Pendidikan Jasmani

https://ejournal.unib.ac.id/index.php/kinestetik/index

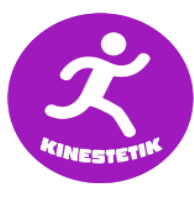

DOI : 10.33369/jk.v5i4.19764

\title{
PJOK LEARNING MODEL ON PENCAK SILAT MATERIAL: LITERATUR REVIEW
}

Heni Yuli Handayani ${ }^{1 *}$, Septyaningrum Putri Purwoto ${ }^{2}$, Agus Himawan ${ }^{3}$

${ }^{123}$ Sports Education Study Program, STKIP PGRI Bangkalan

Article Info

Article History :

Received: December 2021

Revised : December 2021

Accepted : December

2021

Available online :

December 2021

\section{Keywords:}

learning model, pencak silat material

\begin{abstract}
The learning process that has been going on so far for PJOK teachers in classroom management still tends to be centered on the teacher as the main learning resource (teacher centre). In the physical education learning process, there are various sports that can be used as a means to improve students' psychomotor aspects. One of them is pencak silat. Learning material for Pencak Silat is still limited to direct teacher demonstrations or models. Therefore, an appropriate learning model is needed to be applied in the learning of pencak silat material. Learning models in the pencak silat material include project based learning (PBL) learning models assisted by picture cards, multimedia learning models, move color learning models, jigsaw cooperative learning, NHT type cooperative learning models, and also direct instruction learning models.
\end{abstract}

Corresponding address : Jl. Soekarno Hatta No.52, Wr 07,

Mlajah, Kec. Bangkalan, Kabupaten Bangkalan, Jawa Timur

*Corresponding email : heni@stkippgri-bkl.ac.id
ISSN 2685-6514 (Online)

ISSN 2477-331X (Print) 


\section{INTRODUCTION}

The learning process that has been going on so far for PJOK teachers in classroom management still tends to be centered on the teacher as the main learning resource (teacher centre). In the physical education learning process, there are various sports that can be used as a means to improve students' psychomotor aspects. One of them is pencak silat (Ginanjar \& Ramadhan, 2021).

Learning material for Pencak Silat is still limited to direct teacher demonstrations or models. Whereas pencak silat is a very complex learning because it consists of various basic techniques and takes a long time to learn (Prathami, Suwiwa, \& Astra, 2017). This is a fundamental problem in education, especially in learning the material for pencak silat.

Education, especially in schools, will not be far from the name of the learning process. The learning process in which there is a process of interaction between teachers and students and between students to achieve a goal, namely changes in student attitudes and behavior. In the learning process, learning outcomes can be seen directly. Therefore, in order to be controlled and developed optimally through the learning process in the classroom, the learning program must be designed in advance by the teacher by taking into account various principles that have been proven empirically superior. (Putu Ryan Dharma Putra, Artanayasa, \& Spyanawati, 2017). This should get special attention for a teacher.

At the education unit level, especially in the subjects of Physical Education, Sports and Health (PJOK), Pencak silat is one of the materials taught in schools. Considering that the material for pencak silat is very important to be mastered by students at the education unit level, a teacher must try to create a conducive learning atmosphere or conditions so that learning achieves goals effectively and efficiently.

PJOK teachers should no longer teach only as an activity to convey knowledge, skills, and attitudes to students. Learning material for pencak silat should require students to be able to develop their own knowledge, learn independently, while the teacher acts as a facilitator, mediator, and manager of the learning process. Optimizing movement activities, creativity, and the role of students are expected to be able to develop their potential and learning capacity, as well as the potential of learning resources around them (Prathami, Suwiwa, \& Astra, 2017).

Previous research stated that the application of the project-based learning model with the aid of picture card media had a significant effect on improving learning outcomes for the basic techniques of pencak silat (Prathami, Suwiwa, \& Astra, 2017). Research entitled The Effect of Direct Instruction Learning Model on Basic Pencak Silat Front Kick Techniques for Madrasah Tsanawiyah Students resulted that there was an effect of DI learning model on the basic techniques of front kick pencak silat MTs students (Ginanjar \& Ramadhan, 2021).

On the basis of the above background, it is necessary to conduct a literature review review of the PJOK 
Learning Model on the Pencak Silat Material.

\section{METHODS}

The purpose of the study was to determine the PJOK learning model on the material of Pencak Silat. This type of research uses qualitative research with literature review methods. The literature selection technique is based on the keywords of the pencak silat learning model. The literature comes from national journals on Google Scholar with a publication limit of the last 10 years. The literature study technique uses a synthetic matrix based on reference sources, sample types, methods, interventions, and findings.

\section{RESULT}

A total of 7 national journals have been reviewed based on reference sources, sample types, research methods, interventions provided and findings. The review process aims to find and analyze the PJOK Learning Model on the Pencak Silat Material.

1. Research entitled the effect of project based learning (PBL) learning model assisted by picture card media on learning outcomes of basic techniques of pencak silat horses. This research is a real experimental research using the randomized pretest posttest control group the same subject design. The population is class $\mathrm{X}$ SMA Lab Undiksha 2017/2018 academic year which is distributed into five classes with a total of 106 members (51 male and 55 female). The sample was obtained by simple random sampling technique. Learning outcomes data were collected through multiple choice tests, observation and performance. The results show that the application of the project-based learning model with the aid of picture cards has a significant effect on improving learning outcomes for the basic techniques of pencak silat. (Prathami, Suwiwa, \& Astra, 2017).

2. Research with the title of project based learning learning model with the aid of pictorial card media on the learning outcomes of the basic techniques of pencak silat kicks. This research is a real experimental research with the randomized pretest posttest control group the same subject design. The population of this research is class XI SMA Lab Undiksha 2017/2018 academic year which is distributed into nine classes with a total of 232 members. Samples were taken using simple random sampling. The sample class is class XI IPA 2 as the experimental group and class XI IPA 3 as the control group. The results show that the application of the projectbased learning model with the help of picture card media has a significant effect on improving learning outcomes for the basic techniques of pencak silat kicks. (Mudianti, Astra, \& Suwiwa, 2018).

3. Research with the title Development of Learning Models Using Multimedia in Pencak Silat Learning in a Pandemic Period. This study uses a qualitative method, the source of the data for this research is the fourth grade students of SDN Wonokerto IV in the 2020/2021 
academic year, which consists of a small group of 5 students. This data collection technique uses the method of observation and questionnaires to material experts, media experts and students. The results of the material expert validation were "Very Good" with a score of 4.80 and media experts rated 4.60 in the "Good" category. The assessment of the students tested was "Very Good" with an average score of 4.75. So it can be concluded that the product developed is feasible to be used in the learning process. Multimedia development in learning pencak silat Physical education, sports and health can increase student motivation and learning outcomes during the pandemic in grade IV Wonokerto State Elementary School IV (Wahyudi, Qurtubi, \& Prayoga, 2021).

4. The title of the research is Implementation of Improving Learning Outcomes of Basic Pencak Silat Techniques Through the Move Color Learning Model for Male Students in Grades 4 and 5 of IT Abu Jafar Elementary School for the 2020/2021 Academic Year. The subjects consisted of male students in grades 4 and 5 of SD IT Abu Jafar for the academic year 2020/2021 totaling 32 students. The data source comes from students. Collecting data with performance tests. Basic skills of pencak silat (Psychomotor), Observation of Student Attitudes (Affective), and Student Knowledge (Cognitive) which are recapitulated during activities The learning process takes place through the Move Color learning model. The data analysis technique used descriptive analysis of the results of the complete learning outcomes obtained by students. The results of student learning completeness are only $31.25 \%$ with an average value of 68.68 (rounded 68.7) and after doing Action I, it produces data on student improvement in learning basic techniques of pencak silat through the Move Color learning model. Completeness of learning outcomes of basic pencak silat techniques from Initial Conditions to Cycle I increased by $31.25 \%$ to $62.50 \%$ with an average value of 74.43 . From Cycle I to Cycle II there was an increase of $18.75 \%$ to $81.25 \%$. Based on the results of Community Service, it is concluded that: through the Move Color learning model, it can improve learning outcomes of basic pencak silat techniques in male students in grades 4 and 5 of SD It Abu Jafar for the 2020/2021 academic year (Jasmani \& Kusuma, 2021).

5. This research is entitled Application of Jigsaw Type Cooperative Learning Model Using Rubber Tire Media to Improve Sickle Kick Footwork Skills in Pencak Silat Learning. The research method used is Classroom Action Research (CAR). The research was carried out at Gegerkalong State Elementary School I KPAD Bandung City with the object of research being fourth grade students, totaling 28 students. The overall average value of the initial data is $36.14 \%$ and the first cycle of action I is $42.64 \%$, the first cycle of action II is $51.14 \%$, the second cycle of action I is $62.14 \%$, and the 
second cycle of action II is $71,57 \%$. From the average aspect of the sickle kick footwork skill based on the results of data analysis, it can be concluded that the application of the Jigsaw type cooperative learning model can improve the sickle kick footwork skill. (Fajari \& Suhendi, 2017).

6. The research entitled the effect of the NHT type cooperative learning model on the learning outcomes of the basic techniques of pencak silat stroke. This research is a real experimental research using the randomized pretest-posttest control group research design. The population in this study were all eighth grade students of SMP Negeri 2 Banjar in the 2018/2019 academic year. The results of this study indicate that the NHT type of cooperative learning model has a very significant effect on increasing student learning outcomes in basic techniques of pencak silat stroke (Suriantika, Rai, \& Suwiwa, 2019).

7. PThe research entitled The Effect of Direct Instruction Learning Model on Basic Pencak Silat Front Kick Techniques for Madrasah Tsanawiyah Students. The research method uses an experiment with a One-Group PretestPosttest design. The participants in this study were 22 MTs students in one of Indramayu Regency, West Java Province, which were taken using a saturated sampling technique. The research instrument used an observation sheet for the basic movements of the pencak silat front kick. The data analysis technique used t-test: paired two sample for means. The results of the study concluded that there was an effect of the DI learning model on the basic techniques of the front kick of pencak silat MTs students (Ginanjar \& Ramadhan, 2021).

\section{DISCUSSION}

The results of the study obtained several learning models, including project based learning (PBL) learning models assisted by picture cards, multimedia learning models, move color learning models, jigsaw cooperative learning, NHT cooperative learning models, direct instruction learning models. Based on these results indicate that there are several methods that can be applied in learning pencak silat.

The project-based learning model requires students to produce a project or work so that students will become more active in learning and students can also remember the material longer. (Mudianti, Astra, \& Suwiwa, 2018).

The DI learning model has the theme "teacher as instructional leader". So the teacher can be said to be a full instructional leader. The purpose of this model is to use the time as efficiently as possible in the available study time and increase the use of study time by students in carrying out various tasks and skills, so the teacher helps students to have high responsiveness, feedback, and to make appropriate learning steps. stable and positive towards the desired learning content. With the physical education paradigm more often it focuses on the use of sports as a means of fulfilling the psychomotor aspects of students, plus teachers more often use conventional learning, so that students do not get 
feedback from the learning process. Then this DI learning model can be used as a tool that can help teachers further improve physical education learning outcomes, especially pencak silat learning materials (Ginanjar \& Ramadhan, 2021).

Multimedia or audio-visual learning models provide a lot of stimulus to students because the nature of audiovisual or images can encourage students to develop communication skills and express their thoughts (Fitriyani, 2019). Audio visual media can train students' concentration and focus on the material being taught but it can also attract students' attention (Susilo, 2020). Video is a medium that can be seen and heard by the human senses that is effectively used en masse, individually or in groups (Hadi, 2017).

In learning pencak through Jigsaw type cooperative learning, a conducive learning atmosphere will be created communicative communication between students with one another so that social communication occurs which is expected to foster student collaboration skills both when learning takes place at school or outside school. In addition, students who have low abilities will feel cared for so that there is no longer a sense of awkwardness. Feelings of inferiority or reluctance to join high-skilled students, thus the learning expected by the teacher, namely interactive and communicative learning can be created and the goals of physical education can be achieved as a whole (Fajari \& Suhendi, 2017).

In addition, the NHT type of cooperative learning model is also suitable in improving students' learning outcomes of basic pencak silat stroke techniques (Suriantika, Rai, \& Suwiwa, 2019).

\section{CONCLUSION}

The learning models in the pencak silat material are project based learning (PBL) learning models assisted by picture cards, multimedia learning models, move color learning models, jigsaw cooperative learning, NHT cooperative learning models, and also direct instruction learning models.

\section{ACKNOWLEDGEMENT}

Thank you to the team who helped in the completion of this article. And don't forget to thank the family who always provide support.

\section{REFERENCES}

Fajari, A. M.;\& Suhendi, H. (2017). Penerapan Model Pembelajaran Kooperatif Tipe Jigsaw Menggunakan Media Karet Ban Untuk Meningkatkan Keterampilan Gerak Kaki Tendangan Sabit Dalam Pembelajaran Pencak Silat. Journal of Teaching Physical Education In Elementary School, 1(1), 75-84.

Fitriyani, N. (2019). Pengembangan Media. Jurnal Tunas Bangsa, 6(1), 104-114.

Ginanjar, A.;\& Ramadhan, R. (2021). Pengaruh Model Pembelajaran Direct Instruction Terhadap Teknik Dasar Tendangan Depan Pencak Silat Siswa Madrasah Tsanawiyah. Jurnal Kependidikan Jasmani dan Olahraga, 2(1), 1-8. 
Hadi, S. (2017). Efektivitas Penggunaan Video Sebagai Media. Prosiding TEP \& PDs.

Hausal, H., Lubis, J., \& Puspitorini, W. (2018). Model Latihan Teknik Dasar Serangan Tungkai Pencak Silat Berbasis Media Belajar. Jurnal Pendidikan Jasmani Dan Adaptif, 1(02), 58-63.

Halbatullah, K., Astra, I. B., \& Suwiwa, I. G. (2019). Pengembangan Model Latihan Fleksibilitas Tingkat lanjut Dalam pembelajaran Pencak Silat. Jurnal Ika, 17(2), 136-149.

Iswana, B., \& Siswantoyo, S. (2013). Model latihan keterampilan gerak pencak silat anak usia 9-12 tahun. Jurnal Keolahragaan, 1(1), 2636.

Jasmani;\& Kusuma, I. A. (2021). Implementasi Meningkatkan Hasil Pembelajaran Teknik Dasar Pencak Silat Melalui Model Pembelajaran Move Colour Pada Siswa Putra Kelas 4 Dan 5 Sd It Abu Jafar Tahun Ajaran 2020/2021. PROFICIO: Jurnal Pengabdian Kepada Masyarakat, 2(2), 1-4.

Kriswanto, E. S. (2008). Model Pembelajaran dan Prinsip Bermain Pencak Silat untuk Anak Prasekolah. Jurnal Pendidikan Jasmani Indonesia, 5(1).

Mudianti, N. P.;Astra, I. K.;\& Suwiwa, I. G. (2018). Pengaruh Penerapan Model Pembelajaran Project Based Learning Dengan Berbantuan Media Kartu Bergambar Terhadap Hasil Belajar Teknik Dasar Tendangan Pencak Silat. E_Journal Pendidikan Jasmani, Kesehatan dan Rekreasi, 8(2), 1-9.

Prathami, I. A.; Suwiwa, I. G.;\& Astra, I. K. (2017). Pengaruh Model Pembelajaran Project Based Learning Berbantuan Media Kartu
Bergambar Terhadap Hasil Belajar Teknik Dasar Kuda-Kuda Pencak Silat. E_Journal Pendidikan Jasmani, Kesehatan dan Rekreasi, 8(2), 1-8.

Putu Ryan Dharma Putra;Artanayasa, I. W.;\& Spyanawati, N. L. (2017). Pengaruh Penerapan Model Pembelajaran Kooperatif Tipe Student Teams Achievement Division Berbantuan Media Gambar Terhadap Hasil Belajar Passing Sepakbola. E_Journal Pendidikan Jasmani, Kesehatan dan Rekreasi, 8(2), 1-9.

Septiadi, A., \& Widiastuti, H. (2019). Model Latihan Speed Endurance Berbasis Senam Pencak Silat Untuk Usia Remaja. Journal Sport Area, 4(2), 285-293.

Suriantika, I. K.;Rai, I. W.;\& Suwiwa, I. G. (2019). Pengaruh Model Pembelajaran Kooperatif Tipe Numbered Head Together (Nht) Terhadap Hasil Belajar Teknik Dasar Pukulan Pencak Silat. Jurnal Pendidikan Jasmani Olahraga Dan Kesehatan, 7(1), 37-44.

Susilo, S. V. (2020). Penggunaan Media. Jurnal Cakrawala Pendas, 6(2), 108-115.

Wahyudi, A. N.;Qurtubi, A. Z.;\& Prayoga, A. S. (2021). Pengembangan Model Pembelajaran Dengan Multimedia Dalam Pembelajaran Pencak Silat di Masa Pandemi. Indonesia Journal of Learning Education and Counseling, 3(2), 156-163. 